\title{
Examining the Relationship between Metacognitive Awareness and Success Orientations of Physical Education and Sports Teacher Candidates
}

\author{
Barış Karaoğlu \\ Bingol University, Turkey \\ Mehmet Behzat Turan \\ Erciyes University, Turkey
}

Doi:10.19044/ejes.v7no3a3 URL:http://dx.doi.org/10.19044/ejes.v7no3a3

\begin{abstract}
The present study aims to investigate the relationship between metacognitive awareness and success orientations of physical education and sports teacher candidates. The population of the research consisted of 240 teacher candidates studying in the third and fourth grades in physical education and sports teaching departments at Bozok, Erciyes, and Mehmet Akif Ersoy Universities, and 142 students who were selected with random sampling method consisted the sample group. In the collection of the data, the Personal Information Form, Metacognitive Awareness Inventory and Success Orientation were used. The obtained data were analyzed in the computer environment. Number, percentage, average, and standard deviation were used as descriptive statistical methods in the evaluation of the data. Pearson correlation analysis was used between the continuous variables of the study.

As a result, it was determined that the metacognitive awareness of the physical education teacher candidates was low, the learning orientation and the tendency for performance from the sub-headings of success orientation were high and medium, respectively, and the avoid of performance tendency was medium, and there was a low negative relationship between the metacognitive awareness and the avoid of performance tendency which is among the sub-headings of success orientation. It can be stated that this situation originates from the fact that the physical education teacher candidates possess certain levels of sports skills, knowledge and achievements in the sportive life that started and/or still continue before the university education, and from the thoughts of avoiding negative judgments by performing their skills as well as learning new skills.
\end{abstract}

Keywords: Students, Physical Education, Sports, Metacognitive Awareness, Success Orientation. 


\section{Introduction}

Technological developments from past to present cause important innovations in human history (Karakuş \& Köse, 2018) and constantly lead people to reach more perfection (Karakuş, 2012). Accordingly, the educational qualifications required for the development of individuals change as well. Darling-Hammond (2000) stated that educational research focuses on acquiring high-level mental qualities such as accessing information, obtaining information, and managing their own mental processes, rather than conveying existing information to individuals. In this sense, when it is considered that students are responsible for their self-learning, the concept of metacognitive emerges. In general terms, metacognitive is not only important in terms of acquisition efficiency, understanding, remembering, and practicing what has been learned, but also effective in the acquisition of effective learning, critical thinking, and problem-solving skills (Hartman 1998). Metacognitive awareness (Çakıroğlu, 2007) is defined as "cognition of knowing" in its simplest sense. In this respect, metacognitive awareness is one of the most important variables in predicting learning and increasing success (Okoza, Aluede, \& Owens-Sogolo, 2013).

Metacognitive control is the individual's review of his own learning process and learning products at the end of the monitoring process, and conscious or unconscious decisions made depending on the result (Schwartz \& Perfect, 2002: 6). In other words, it is the ability to strategically use metacognitive knowledge to achieve cognitive goals (Demircioğlu, 2008). Metacognitive control strategies include the conscious control of learning by the individual, planning, strategy selection, monitoring the learning process, correcting errors, analyzing the effectiveness of learning strategies, and changing cognitive strategies when necessary (Ridley et al., 1992). An individual who can control his / her learning process with metacognitive control strategies can reach the goal determined at the beginning of the process in the most appropriate way and in the shortest time. Because the individual will continuously monitor and evaluate the learning process with metacognitive control strategies and will be able to change the strategies used when necessary.

Success is a concept that describes achieving the previously set targets or to what extent the goal would be achieved. Accordingly, success orientation implies that individuals tend to be determined to use their time and energy to achieve their goals (Küçükoğlu, Kaya, \& Turan, 2010).

According to success tendencies approach that were conceptualized by Dweck et al. (Ames, 1992; Dweck \& Legget, 1988; Nicholls, 1984); in all kinds of learning environment, there are 3 main academic targets that lead students' attitudes and behaviors to materials and academic duties that should be learnt: learning tendency approach, tendency for performance and 
avoidance of performance tendency. The main aim of students with learning tendency approach is to learn the related content and obtain the related knowledge and abilities. The main aim of students with tendency for performance is to approve their academic superiority and sufficiency levels compared to others as showing a higher success level related to the material that must be learnt. On the other hand, avoidance of performance tendency is defined with such behaviors as trying to finish responsibilities related to learning as obtaining an acceptable pass score with minimum effort (Özgüngör, 2014). Will of students in schools of physical education and sports teaching to be more successful in terms of sports, starting from their childhood periods, their families' and societies' parallel will in this subject positively affect students' success tendencies due to they do not have any conflicts in this subject (Pepe 2015).

In an environment focusing on metacognitive abilities, it is important to acknowledge the situation of teacher candidates' success orientation in terms of guiding teacher training policies and raising successful students in the following years.

According to the literature review made by the author, there are studies examining metacognitive awareness (Akın, 2006; Zorlu, Zorlu, \& Dinç, 2019; Karakelle, 2012; Bakioğlu et al., 2015) and success orientation (Koç, \& Gözler, 2019; Pepe, 2015; Özgüngör, 2014; Turan, Karaoğlu, \& Koç, 2017). However, there were not any studies examining the metacognitive awareness and success orientation of physical education and sports teacher candidates. The present study aims to investigate the relationship between the metacognitive awareness levels and success orientations of physical education and sports teacher candidates.

\section{Method}

\section{Research Model}

This study was designed with a descriptive and correlational survey model. These survey models can be defined as "research models aiming to determine the presence and/or degree of covariance between two and more variables" (Karasar, 2007).

Forming the Voluntary Groups: The population of the research consisted of 240 teacher candidates studying in the third and fourth grades in physical education and sports teaching departments at Bozok, Erciyes, and Mehmet Akif Ersoy Universities, and 142 students who were selected with random sampling method (Çıngı, 1994) consisted the sample group.

Data Collection Techniques: Personal information form prepared by the researcher, metacognitive awareness, and success orientation scales were used in order to collect data in the study. 
Personal information form: The scale includes five questions in order to obtain information about the participants' gender, age, education university, cumulative grade point average, and weekly studying duration.

Metacognitive Awareness Scale: It is a five-point Likert-type scale consisting of 52 items and developed by Schraw and Sperling-Dennison (1994) and adapted to Turkish by Akın, Abacı, and Çetin (2007). It was reported that the Cronbach's Alpha internal consistency coefficient of the whole scale was 0.95 . The scale is also evaluated as sub-headings or as the total score. The lowest score that can be obtained from the scale is 52 and the highest score is 260. A conclusion can be reached about the level of metacognitive awareness of the individuals by dividing the total score obtained from the scale to the number of items.

Success Orientation Scale: "Success Tendencies Scale" that was developed by Midgley et al., and adapted to Turkish by Akın and Çetin (2007) was used as a data collection tool in this research. The original form of Success Tendencies Scale is composed of 18 questions and the first 6 questions are related to learning tendencies, the following six questions are related to tendency for performance and the last six questions are related to avoidance of performance tendencies. On the other hand, the Success Tendencies Scale that was used in this research is composed of 17 items. These 17 items in Success Tendencies Scale are distributed as follows; 1-6 items are about learning tendencies, 7-12 items are about tendency for performance and 13-17 questions are about avoidance of performance tendency. The scale employs 5item Likert type evaluation format as " $1=$ Never", " 2 =Rarely", " $3=$ Often", " 4 $=$ Generally" and " 5 =Always".

\section{Statistical Results}

The application of the Shapiro-Wilk test is just one of the methods used to examine the normality. According to the statistics of the obtained data, skewness and kurtosis distributions are given in Table 1.

Table 1. Skewness-Kurtosis and Shapiro-Wilk Test Level of Significance Results of Participants' Scale Scores

\begin{tabular}{llll}
\hline & $\mathbf{N}$ & Skewness & Kurtosis \\
\hline Metacognitive Awareness & 142 & .567 & -.042 \\
\hline Learning Tendency & 142 & -.723 & -.235 \\
Tendency for Performance & 142 & -.777 & .457 \\
$\begin{array}{l}\text { Avoid of Performance } \\
\text { Tendency }\end{array}$ & 142 & .076 & -.788 \\
\hline
\end{tabular}

When the Shapiro-Wilk Test results are analyzed, it was observed that the deviation from the normality of the scores obtained by the participants 
from metacognitive awareness and success orientation scales was at significant levels (Table. 1). When the normal distribution curves were examined, it was observed that there were no excessive deviations from normality. In the literature, George and Mallery (2016) stated that skewness and kurtosis values are ideally acceptable for values between \pm 1 . Accordingly, it was decided to use parametric statistical analysis tests. The obtained data were analyzed in the computer environment. Number, percentage, average, and standard deviation were used as descriptive statistical methods in the evaluation of the data. Pearson correlation analysis was used between the continuous variables of the study.

Findings

Table 2: The Demographical Features of the Participants

\begin{tabular}{|c|c|c|c|}
\hline & Variables & $\mathbf{N}$ & $\%$ \\
\hline \multirow{4}{*}{ Gender } & Male & 85 & 59.9 \\
\hline & Female & 57 & 40.1 \\
\hline & Total & 142 & 100 \\
\hline & $18-21$ & 65 & 45.8 \\
\hline \multirow[t]{3}{*}{ Age } & 22 and above & 77 & 54.2 \\
\hline & Total & 142 & 100 \\
\hline & MAKÜ & 45 & 31.7 \\
\hline \multirow{3}{*}{ University } & Erciyes & 44 & 31.0 \\
\hline & Bozok & 53 & 37.3 \\
\hline & Total & 142 & 100 \\
\hline Cumulative & $1.25-1.99$ (Low) & 17 & 12.0 \\
\hline Grade & 2.00-2.99 (Medium) & 69 & 48.6 \\
\hline \multirow[t]{2}{*}{ Average } & 3.00-4.00 (High) & 56 & 39.4 \\
\hline & Total & 142 & 100 \\
\hline Weekly & $1-10$ & 94 & 66.2 \\
\hline \multirow{2}{*}{ Hours } & 11 and above & 48 & 33.8 \\
\hline & Total & 142 & 100 \\
\hline
\end{tabular}

When Table 2 is examined, it was determined that $59.9 \%$ of the participants were male and $40.1 \%$ of them were female, $45.8 \%$ of them were between the age of 18-21 years old and $54.2 \%$ of them were 22 and above years old, $\% 31.7 \%$ of them were studying at Mehmet Akif Ersoy University, $31 \%$ of them were studying at Erciyes, $37.3 \%$ of them were studying at Bozok University, $12 \%$ of them had low CGPA, $48.6 \%$ of them had medium CGPA, $39.4 \%$ of them had high CGPA, and $66.2 \%$ of them were studying 1-10 hours a week and $33.8 \%$ of them were studying 11 and more hours a week. 
Table 3: Descriptive Statistics of the Scores Obtained from the Scales

\begin{tabular}{|c|c|c|c|c|}
\hline & $\mathbf{N}$ & Min & Max & $\mathbf{X} \pm$ Sd \\
\hline Metacognitive Awareness & $\begin{array}{l}14 \\
2\end{array}$ & 1.69 & 3.46 & $2.44 \pm .37$ \\
\hline Learning Tendency & $\begin{array}{l}14 \\
2\end{array}$ & 3.00 & 5.00 & $4.34 \pm .49$ \\
\hline Tendency for Performance & $\begin{array}{l}14 \\
2\end{array}$ & 1.67 & 5.00 & $4.07 \pm .72$ \\
\hline Avoid of Performance Tendency & $\begin{array}{l}14 \\
2 \\
\end{array}$ & 1.00 & 5.00 & $3.00 \pm .96$ \\
\hline
\end{tabular}

When Table 3 is analyzed, it was determined that the metacognitive awareness of the physical education and sports teacher candidates who participated in the study was $2.44 \pm .37$, their Learning Tendency score was

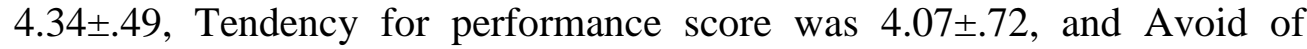
Performance Tendency was 3.00土.96.

Table 4: The Relationship between the Metacognitive Awareness and Success Orientation of the Participants

\begin{tabular}{|c|c|c|c|c|c|}
\hline & & 1. & 2 & 3 & 4 \\
\hline \multirow{3}{*}{ 1. Metacognitive Awareness } & $\mathbf{r}$ & 1 & & & \\
\hline & p & & & & \\
\hline & n & 142 & & & \\
\hline \multirow{3}{*}{ 2. Learning Tendency } & $\mathbf{r}$ & -.029 & 1 & & \\
\hline & $\mathbf{p}$ & .731 & & & \\
\hline & $\underline{\mathbf{n}}$ & 142 & 142 & & \\
\hline \multirow{3}{*}{$\begin{array}{l}\text { 3. Tendency } \\
\text { Performance }\end{array}$} & $\mathbf{r}$ & -.017 & .146 & 1 & \\
\hline & $\mathbf{p}$ & .837 & .084 & & \\
\hline & $\underline{\mathbf{n}}$ & 142 & 142 & 142 & \\
\hline \multirow{3}{*}{$\begin{array}{l}\text { 4. Avoid of Performance } \\
\text { Tendency }\end{array}$} & $\mathbf{r}$ & -.197 & .167 & .217 & 1 \\
\hline & & .019 & .047 & .010 & \\
\hline & $\mathrm{n}$ & 142 & 142 & 142 & 142 \\
\hline
\end{tabular}

When Table 4 is examined, a negative and low relationship was determined between the metacognitive awareness and avoid of performance tendency from the sub-headings of success orientation of the physical education and sports teacher candidates. 


\section{Discussion and Conclusion}

Today, sports are used as a powerful educational tool in the solution of social problems by broadening the area of interest in order to meet the various expectations of individuals (Akınc1, 2019). The participation of students to the sports based physical activities increased their quality of life and socialization, and had a positive effect on their academic success (Y1ldirım, \& Bayrak, 2019).In this context, it is important to acknowledge how the physical education and sports teacher candidates are in a learning environment with a focus on the metacognitive abilities, to create a quality teaching-learning process, and transfer the future generations when they start their professional life in the future.

It was determined that the metacognitive awareness of the physical education and sports teacher candidates was low, and the learning tendency and tendency for performance were higher and avoid of performance tendency was medium. Akın, Abacı and Çetin (2007) reported that metacognitive awareness was low for individuals who had an average score below 2.5 and high for those who had higher than 2.5.

When the literature is examined, there are studies reporting that the metacognitive awareness of teacher candidates (Zorlu, Zorlu, \& Dinç, 2019), preschool teachers (Baba Öztürk, \& Güral, 2016), and classroom and science teachers (Bakioğlu et al., 2015) are high. . In another study, Şahin and Küçüksüleymanoğlu (2015) reported that classroom, physical education and sports, Turkish, counseling and psychological counseling, foreign language, music, science, social studies, and mathematics teacher candidates had high metacognitive awareness levels and preschool teacher candidates had low metacognitive awareness levels. In the present study, it was unexpected that metacognitive awareness levels of physical education teacher candidates would be low. This situation is considered to originate from the socio-cultural characteristics of the sample group participating in the study or individual differences that may be among the participants in other studies in the literature.

When the success orientation of the physical education and sports teacher candidates are examine as a whole, it was observed that their learning orientation was quite high, and the least adopted orientation is avoid of performance tendency. When the studies examining the success orientation in the literature are examined, there are studies on teacher candidates (Arslan 2011, Gözler, Bozgeyikli and Avc1, 2017), Aydın, 2014) and students (Koç, \& Gözler, 2019; Pepe, 2015; Turan, Karaoğlu, \& Koç, 2017) that support the findings in this study. It can be stated that the participation of physical education and sports teacher candidates to the activities may originate from the idea of learning new information as well as appearing more successful and talented and avoiding negative attitudes that would be directed towards them. 
There was a low negative correlation between the metacognitive awareness of physical education and sports teacher candidates and avoid of performance tendency which is one of the sub-headings of success orientation (Table 4). When the literature is examined, there are studies indicating that metacognitive awareness has a positive relationship with readiness to selfregulated learning (Şahin, \& Küçüksüleymanoğlu, 2015), attitude towards technology (Bakioğlu et al., 2015), life skills (Zorlu, Zorlu, \& Dinç, 2019), negative relationship with personal problem-solving perception (Karakelle, 2012), and no relationship with self-respect (Koç, \& Gözler, 2019).

The aim of education is to provide students with the knowledge and skills they can use in daily life. The ability of students to benefit from teaching activities depends on many factors, however, it is also related to their desire to learn the material and for what purpose they want to learn (Arslan, 2011). Mental processes such as metacognitive awareness, high-level thinking, knowledge of own cognitions, developing self-evaluation skills, determining the strategies that cause success or failure (Schraw and Dennison, 1994) and it is accepted as an element of learning skill and information effectively (Çetinkaya, \& Erktin, 2002). Success orientation refers to mental processes and activities resulting from the desire to achieve goals (DeShon, \& Gillespie, 2005). According to the theory of success, it is the result of the tendency to approach and avoid failure or the conflict between the hope of success and fear of failure (Küçükoğlu, Kaya, \& Turan, 2010). Individuals with a high motivation for success are people who study to learn, set common goals, have developed feelings of competence, undertake effort, and try to overcome difficulties when they encounter. Individuals with low motivation, on the other hand, are people who try to appear that they have learned, set goals that they can easily reach or cannot reach, do not have developed feelings of competence, use external factors as excuses, and get frustrated when faced with difficulties. Upbringing, former successes and failures have great importance in the emergence of the motivation for success. People who had the opportunity to try and discover their talents and enjoy the success of their childhood will also have high motivation for success (Açıkgöz, 2000).

In conclusion, the relationship between the metacognitive awareness levels and avoid of performance tendency, which is one of the sub-headings of success orientation, in physical education teacher candidates may derive from the fact that students try to avoid negative judgments by performing their skills as well as learning new skills in educational processes and possessing a certain level of sportive skills, knowledge, and achievements in their athletics life started before the university and/or still continues. 


\section{Recommendations}

I. Training and studies can be increased to determine the metacognitive awareness levels of teacher candidates in physical education and sports teacher education programs.

II. In the curriculum programs, teacher candidates in physical education and sports teaching programs can be taught to increase their metacognitive awareness levels.

III. A comparison can be made with the results of this research by conducting a study with the teacher candidates in physical education and sports teacher education programs at different universities.

\section{References:}

1. Açıkgöz, K.Ü. (2000). Etkili öğrenme ve öğretme. Kanyıldız Matbaası, İzmir. 25-26

2. Akın, A. (2006). Başarl amaç oryantasyonlarl ile bilişötesi farkındalık, ebeveyn tutumları ve akademik başarı arasındaki ilişkiler. Yayınlanmamış yüksek lisans tezi. Sakarya Üniversitesi, Sosyal Bilimler Enstitüsü. 19

3. Akın, A., \& Çetin, B. (2007). Başarı yönelimleri ölçeği, geçerlik ve güvenirlik çalışması. Eğitim araştırmaları, 26.

4. Akın, A., Abacı, R., \& Çetin, B. (2007). The validity and reliability of the Turkish version of the metacognitive awareness inventory. Educational Sciences: Theory\&Practice, 7(2), 671-678.

5. Akıncı, A. Y. (2019) Beden eğitimi, sosyalleşme ilişkisi, ortaöğretim kurumlarında beden eğitimi ve spor etkinliklerinin sosyalleşme süreci ve şahsiyetin oluşumuna katkısı. Lap Lambert Academic Publishing, Mauritius.

6. Ames, C. (1992). Achievement goals and the classroom motivational climate. In D. H. Schunk \& J. L. Meece (eds.), Student perceptions in the classroom (327-348). Hillsdale, NJ: Erlbaum.

7. Arslan, A. (2011). Öğretmen adaylarının amaç yönelimleri ile yapılandırmacılı̆̆a yönelik görüşlerinin incelenmesi. Ondokuz Mayıs Üniversitesi Eğitim Fakültesi Dergisi, 30(1), 107-122.

8. Aydın, S. (2014). Öğretmen adaylarının başarı amaç yönelimleri ve akademik öz-yeterliklerinin yapısal eşitlik modeliyle incelenmesi. Turkish Studies - International Periodical For The Languages, Literature and History of Turkish or Turkic, 9(2), 221-230.

9. Baba Öztürk, M., \& Güral, M. (2016), Okul öncesi öğretmen adaylarının bilişötesi farkındalık düzeylerinin çeşitli değişkenler açısından incelenmesi. Turkish Studies International Periodical for the Languages, Literature and History of Turkish or Turkic, 11(19), 107132. 
10. Bakioğlu, B., Alkış, Küçükaydın, M., Karamustafaoğlu, O., Uluçınar Sağır, Ş., Akman, E., Ersanlı, E., \& Çakır, R. (2015). Investigation of prospectıve teachers' metacognitive awareness levels, problem solving skills and attitudes towards technology. Trakya University Journal of Education, 5(1), 22-33.

11. Çakıroğlu, A. (2007). Üstbiliş. Türkiye Sosyal Araştırmalar Dergisi, 11(2), 21-27.

12. Çetinkaya, P., \& Erktin, E. (2002). Assessment of metacognition and its relationship with reading comprehension, achievement, and aptitude. Boğazici University Journal of Education, 19(1), 1-11.

13. Çıngı, H. (1994). Örnekleme Kuramı, H.̈̈. Fen Fakültesi Yayınları, Ankara, 346.

14. Darling-Hammond, L. (2000). Teacher quality and student achievement: A review of state policy evidence. Education Policy Analysis Archives, 8 (1), 1-44.

15. Demircioğlu, H. (2008). Matematik öğretmen adaylarının üstbilişsel davranışlarının gelişimine yönelik tasarlanan eğitim durumlarının etkililiği. Yayımlanmamış Doktora Tezi, Gazi Üniversitesi Eğitim Bilimleri Enstitüsü, Ankara.13

16. DeShon, R. P., \& Gillespie, J. Z. (2005). A motivated action theory account of goal orientation. The Journal of Applied Psychology, 90(6), 1096-1127.

17. Dweck, C. S., \& Leggett, E. S. (1988). A social-cognitive approach to motivation and personality. Psychological Review, 95, 256-273.

18. George, D., \& Mallery, P. (2016). IBM SPSS Statistics 23 Step by Step: A Simple Guide and Reference. New York: Routledge; 112-120.

19. Gözler, A., Bozgeyikli, H., \& Avcı, A. (2017). Sınıf öğretmeni adaylarının başarı yönelimleri ile mesleki kaygı düzeylerinin incelenmesi. Abant İzzet Baysal Üniversitesi Eğitim Fakültesi Dergisi, 17 (1), 189-211.

20. Hartman, H. J. (1998). Metacognition in teaching and learning; an introduction, Instructional Science, 26, 1-3.

21. Karakelle, S. (2012). Interrelations between metacognitive awareness, perceived problem solving. Intelligence and Need for Cognition Education and Science, 37(164), 237-250.

22. Karakuş, M. (2012). Termal turizm ve rekreatif etkinlikler açısında kozaklı'nın değerlendirilmesi.Yayınlanmış Yüksek Lisans Tezi. Erciyes Üniversitesi. Sağlık Bilimleri Enstitüsü, Beden Eğitimi ve Spor Anabilim dalı, Kayseri.17-25

23. Karakuş, M., \& Köse, A., (2018). Ülkemizdeki yerli turistlerin nevşehir-kozaklı bölgesindeki termal kaplıca tercihlerindeki faktörler 
ile rekreatif etkinliklerin yeterlilik durumlarının incelenmesi. Spor Bilimleri Alanında Yenilikçi Yaklaşımlar, Gece kitaplı̆̆ , 269-285.

24. Karasar, N. (2007). Bilimsel Araştırma Yöntemi. (17.Baskı), Ankara, Nobel Yayın Dă̆ıtım, 49-53.

25. Koç, K. , \& Gözler, A. (2019) Examination of relationship between self-respect levels and success tendencies of sports sciences faculty students. International Journal of Applied Exercise Physiology, 8(4), 78-87.

26. Küçükoğlu, A., Kaya, H. I., Turan, A. (2010). Sınıf öğretmenliği abd öğrencilerinin başarı yönelimi algılarının farklı değişkenler açısından incelenmesi (Atatürk Üniversitesi Ve Ondokuz Mayıs Üniversitesi Örneği) Firat Üniversitesi Sosyal Bilimler Dergisi, 20(2), 121-135.

27. Midgley, C., Kaplan, A., Middleton, M., Maehr, M. L., Urdan, T., \& Hicks-Anderman, L. (1998). The development and validation of scales assessing students' achievement goal orientations. Contemporary Educational Psychology, 23, 113-131.

28. Nicholls, J. G. (1984). Achievement motivation: Conceptions of ability, subjective experience, task choice, and performance. Psychological Review, 91, 328-346.

29. Okoza, J., Aluede, O., \& Owens-Sogolo, O. (2013). Assessing students' metacognitive awareness of learning strategies among secondary school students in Edo State, Nigeria. Research in Education, 90(1), 82-97.

30. Özgüngör S. (2014). The relationship between identity statuses and achievement orientations according to the level of self - esteem in university students. Pamukkale University Journal of Education Faculty, 35, 33-46

31. Özgüngör, S. (2014). Üniversite öğrencilerinde benlik saygısı düzeyine göre kimlik statüleri ile başarı yönelimleri arasındaki ilişki. Pamukkale Üniversitesi Eğitim Fakültesi Dergisi, (35), 33- 46.

32. Pepe, O. (2015). Predictive power of the success tendency and ego identity status of the university students. Educational Research and Reviews, 10(17), 2447-2454.

33. Ridley, D. S., Schutz, P. A., Glanz, R. S., \& Weinstein, C. E. (1992). Self-regulated learning: The interactive influence of metacognitive awareness and goal setting. Journal of Experimental Education, 60(4), 293-306.

34. Şahin, E., \& Küçüksüleymanoğlu, R. (2015). Öğretmen adaylarının özyönetimli öğrenmeye hazırbulunuşlukları, biliş ötesi farkındalıkları ve denetim odakları arasındaki ilişkiler. Abant İzet Baysal Üniversitesi Eğitim Fakültesi Dergisi, 15(2), 317-334. 
35. Schraw, G., \& Dennison, R. S. (1994). Assessing metacognitive awareness. Contemporary Educational Psychology, (19), 460-475.

36. Schwartz, B.L., \& Perfect, T.J. (2002). Introduction: Toward an applied metacognition. In T. J. Perfect \& B. L. Schwartz (Eds.), Applied metacognition Cambridge University Press. Cambridge.6

37. Turan M. B., Karaoğlu, B., \& Koç, K. (2017). Investigation of the relationship between university students' personal characteristics and success tendencies. Turkish Online Journal of Educational Technology, 318-325

38. Yıldırım, M., \& Bayrak, C. (2019). Üniversite öğrencilerinin spora dayalı fiziksel aktivitelere katılımları ve yaşam kalitelerinin akademik başarı ve sosyalleşme üzerine etkisi (Eskişehir Osmangazi Üniversitesi Örneği). Hacettepe Üniversitesi Ĕ̈itim Fakültesi Dergisi, 34(1), 123144.

39. Zorlu, Y., Zorlu, F., \& Dinç, S. (2019). Investigation of relationships between the preservice science teachers' life skills and metacognitive awareness. Necatibey Faculty of Education Electronic Journal of Science and Mathematics Education, 13(1), 302-327. 